\title{
Toward a Children's Savings and College-Bound Identity Intervention for Raising College Attendance Rates: A Multilevel Propensity Score Analysis
}

\author{
William Elliott ${ }^{1 *}$, Gina Chowa ${ }^{2}$, Vernon Loke ${ }^{3}$ \\ ${ }^{1}$ School of Social Work; University of Pittsburgh, Pittsburgh, USA; \\ ${ }^{2}$ School of Social Work, University of North Carolina, Chapel Hill, USA; \\ ${ }^{3}$ School of Social Work, Eastern Washington University, Cheney, USA. \\ Email: *welliott@ku.edu \\ Received May $24^{\text {th }}, 2011$; revised July $3^{\text {rd }}, 2011$; accepted August $13^{\text {th }}, 2011$.
}

\begin{abstract}
It has been suggested that children's savings programs will be more effective if they are combined with strategies to build children's college-bound identities. In this study we use a multi-level treatment approach to propensity score analysis to test this proposition. Findings suggest that children who have savings and are certain they will graduate from a four-year college are more likely to attend college than their counterparts. Given this, we suggest that children's savings policies designed to increase college attendance rates will be more effective if they include strategies for building children's college-bound identity and college-bound identity programs will be more effective if they are linked to children's savings programs.
\end{abstract}

Keywords: Wealth, Assets, College Attendance, Identity-Based Motivation, Savings, Child Development Accounts (CDAs), College Expectations, PSID

\section{Introduction $^{1}$}

In $2008,55 \%$ of children who graduated high school and were from the lowest family-income quintile enrolled in college compared to $80 \%$ of children who graduated high school and were from the highest-income quintile, a gap of $25 \%$ (Baum, Ma, \& Payea, 2010). A well-recognized barrier to college access among low- and moderate-income children is high college costs (ACSFA, 2010). In recent years, the federal government has increasingly relied on loans such as the Federal Stafford and PLUS loan programs as a way to combat high costs. However, emphasis on loans has led to a growing number of children leaving college burdened with high amounts of debt (College Board, 2009).

Finding new and innovative ways to increase college attendance rates among low- and moderate-income children is a priority in today's global, high tech economy. Researchers have identified a number of factors, including social capital (Porfeli, Wang, Audette, McColl, \& Algozzine, 2009), human capital (Paulsen, 2001), and economic capital (Coleman, 1988) as being key predictors of college attendance. In this study, we focus on economic capital. According to Sirin (2005), economic capital is perhaps the most widely applied contextual variable in research on education. Research shows that, as family resources available to youth increase, their educational performance, high school graduation, and college attendance rates improve (Coleman, Campbell, Hobson, McPartland, Mood, \& Weingeld, 1966). However, it is not merely the amount of re-

${ }^{1}$ This publication is part of the College Savings Initiative, a research and policy design collaboration between the Center for Social Development at Washington University in St. Louis and the New America Foundation in Washington, DC. The College Savings Initiative is supported by the Lumina Foundation for Education and the Bill \& Melinda Gates Foundation.

${ }^{2}$ At this writing, the ASPIRE Act remains on the Congressional agenda (http://www.newamerica.net/publications/policy/aspire_act bill_summary).

${ }^{3}$ For a comprehensive review of research on household assets and children's education see Elliott, Destin, and Friedline (2011). sources but the diversity of the resources that leads to greater academic achievement. As Coleman et al. (1996) posit, children from families of higher SES do better because they are exposed to a wider set of resources that they can tap into to promote learning. While education research has given considerable attention to income as a form of economic capital, assets have been largely overlooked, particularly children's financial assets.

In the last decade, Child Development Accounts (CDAs) have been proposed as a potentially novel and promising mechanism for helping to build children's assets and helping them pay for college (Sherraden 1991). An example of a CDA policy is the America Saving for Personal Investment, Retirement, and Education (ASPIRE) Act. ASPIRE would create "KIDS Accounts," or a savings account for every newborn, with an initial \$500 deposit, along with opportunities for financial education. ${ }^{2}$ Children living in households with incomes below the national median would be eligible for an additional contribution of up to $\$ 500$ at birth and a savings incentive of $\$ 500$ per year in matching funds for amounts saved in accounts. When account holders turn 18 , they would be permitted to make tax-free withdrawals for costs associated with post-secondary education, first-time home purchase, and re-tirement security.

However, it is desirable to conduct advance tests of large scale children's savings policies like the ASPIRE act prior to passing them into legislation. Over the last five years, researchers have conducted a number of tests of CDAs using a variety of proxies. Most of this research has focused on household assets (e.g., Conley, 2001; Destin, 2009; Haveman \& Wolff, 2005; Nam \& Huang, 2009; Williams Shanks \& Destin, 2009). Household assets are most commonly defined as net worth (i.e., total family assets minus debt), liquid assets (i.e., easily converted into cash), and illiquid assets (i.e., hard to convert into cash). It is beyond the scope of this article to provide a comprehensive review of the research in this area. ${ }^{3}$ Briefly, some researchers find that children who live in high wealth house- 
holds are more likely to have higher math and reading scores (Zhan, 2006), higher high school graduation rates (Nam \& Huang, 2009), higher college attendance rates (Conley, 2001), and higher college graduation rates (Zhan \& Sherraden, 2009) than children from low wealth households.

Alongside research on household assets, a less developed body of research has emerged in recent years focusing on when children have savings of their own. Researchers studying children's savings posit that ownership has unique qualities. This is in line with consumer research findings. From a consumer research perspective, ownership instills in people (including children as young as age five) a greater sense of perceived control and sense of self (e.g., Belk, 1988; Furby, 1980). According to Belk (1988), it is through the process of ownership that items such as money, other people, and pets can become part of the self. The greater exercise of power a child has over a possession, such as money, the more closely identified with the self it becomes (Furby, 1978). What makes ownership important is what children perceive that ownership gives them control over - for e.g., a stake in financing college. In a study of 51 fourth grade children in a college savings program, Elliott, Sherraden, Johnson, and Guo (2010) find that children who are in the school savings program are statistically more likely to perceive that saving is a way to help pay for college than children in a comparison group.

The unique effect of ownership may provide low- and moderate-income children with a means to overcome everyday negative signals that result from a lack of family assets. Children's savings make future identities particularly salient, as children are actively involved in the process that is linked to their college goals. For example, in addition to saving for college, it may be that children's savings increases the likelihood that children will actively develop strategies to confront costs beyond saving, such as supplementing their savings with loans and financial aid.

In this study, we build on research on children's savings and their educational outcomes by examining whether children's asset-building programs are stronger when they are designed to build children's expectations for graduating from college along with building their savings. More specifically, we examine whether children who have savings and who are certain they will graduate from a four-year college are more likely to attend college than if they have no savings and are uncertain they will graduate, if they have savings but are uncertain they will graduate, or if they are certain they will graduate but have no savings.

\section{Review of Research}

Over the past several years asset researchers have been investigating the effects of children's savings on children's educational outcomes using the Panel Study of Income Dynamics (PSID) and its supplements the Child Development Supplement (CDS) and the Transition into Adulthood (TA) supplement. To conserve space, only the studies that address the relationship between children's savings and college attendance will be reviewed below. For a complete review of research on children's savings and children's educational outcomes please see Elliott, Destin, and Friedline (2011). We also review relevant research on the relationship between assets and children's college expectations.

\section{Research on Children's Savings and College Attendance and Graduation}

In regards to children's savings and children's college outcomes, Elliott and colleagues have conducted four studies
(Elliott \& Beverly, 2011a-b; Elliott, Constance-Huggins, \& Song, 2011; Elliott \& Nam, in press). In study one, Elliott and Beverly (2011a) examine children's savings effects using an aggregate sample $(\mathrm{N}=1003)$ of Black and White children ages 17 to 23 . They find that children who have designated a portion of their own savings for school purposes are approximately two times more likely to be currently attending college or already graduated. As is the case for all four studies, they account for missing data by using list-wise deletion and test whether missing data are missing completely at random (MCAR) using chi-square and t-tests. Missing data can limit the generalizability of these studies. In this study approximately 280 (28\%) cases are deleted due to missing data.

In study two, Elliott, Constance-Huggins, and Song (2011) examine whether children's savings effects vary by income level. To do this, they use separate samples of low-to-moderateincome (below $\$ 50,000 ; \mathrm{N}=495$ ) children and high-income $(\$ 50,000$ or more; $N=508$ ) children. Due to missing data, 160 $(32 \%)$ cases from the low- to moderate-income sample and 157 $(31 \%)$ cases from the high-income sample are deleted. They find that, among low-to-moderate-income children, those who have savings designated for school are about two times more likely to be currently enrolled in college or to have already graduated. In the case of high-income children, children's savings is not statistically significant. The study authors suggest that this non-significance may support the proposition that having children's savings no longer matters above a certain income threshold. That is, above this threshold, income might be high enough that children cannot reasonably doubt that they will be unable to afford college.

In study three, Elliott and Nam (in press) examine whether children's savings effects vary by race. They use separate samples of Black $(\mathrm{N}=469)$ and White $(\mathrm{N}=534)$ children. In the sample of Black children, $167(36 \%)$ cases are deleted due to missing data, and $183(34 \%)$ cases in the White sample are deleted using list-wise deletion. Findings suggest that children who have designated a portion of their savings for school are two times more likely to be attending college or have graduated from college among both samples of Black and White children.

In the final study, Elliott and Beverly (2011b) restrict the sample to children who are certain they will graduate from a four-year college $(\mathrm{N}=333)$. In this sample, $33(10 \%)$ of cases are deleted in list wise deletion. By restricting the sample, the researchers are able to determine the amount of "wilt" that occurs and whether children's savings helps to reduce it. "Wilt" is the percent of children who expect to graduate from a four-year college prior to leaving high school but do not attend college between the ages of 17 and 23; in other words, wilt describes children who expected to attend college but have not attended in the years immediately following high school graduation. The study finds that more than half of children $(55 \%)$ who do not have savings of their own experience wilt. However, among children who expect to graduate from a four-year college, having basic savings is associated with children being approximately six times more likely to attend college, while children who have designated a portion of their basic savings for school are approximately three times more likely to attend college.

In sum, study four raises some questions about whether positive results associated with children's savings and children's educational outcomes in the other three studies may be being driven by children who have both savings and positive college expectations. On the whole, there is evidence to suggest that children's savings may be positively associated with children's 
college attendance.

\section{Research on Children's Savings and College Expectations}

Elliott conducts four studies that examine the relationship between children's savings and children's college expectations (Elliott, 2009; Elliott \& Beverly, 2011a; Elliott, Choi, Destin, \& Kim, 2011; Elliott, Kim, Jung, \& Zhan, 2010). These four studies use data from the PSID and its supplements. Among these four studies, Elliott and Beverly (2011a) and Elliott, Choi, et al. (2011) are the only studies to use the TA supplement; the other two studies use data from the CDS. Further, all but one study uses list wise deletion to account for missing data. To date, Elliott (2009) is the only asset study focused on household or children's savings, to use multiple imputations to complete missing data. With the exception of one of the four studies (Elliott, Choi, et al., 2011), children's savings studies have focused on children's college expectations as a way to explain the relationship between children's savings and educational outcomes.

In study one, the only study to use multiple imputations, Elliott (2009) finds that children's school savings is a significant predictor of children's math scores when children's college expectations are not included in the model. Second, he finds that children's school savings are a significant predictor of children's expectations. Third, he finds that expectations are a significant predictor of math scores when children's school savings are not included in the model. Finally, when children's college expectations and children's school savings are included in the same model, children's school savings remain significantly related to math scores but the effect is reduced. According to the Baron and Kenny (1986) method of testing mediation, this suggests that children's expectations act as a partial mediator between children's school savings and children's math scores. He also uses bootstrapping and Sobel's test to further test whether indirect effects occur. Both methods confirm that children's school savings have indirect effects on children's math scores that occur through children's college expectations. Elliott (2009) also examines the relationship between the amount of children's school savings and math achievement. He finds that amount is not significant.

In study two, discussed above in the review of college attendance and graduation research, Elliott and Beverly (2011a) also examine the relationship between children's school savings and children's college expectations. According to the Baron and Kenny method, they find that children's college expectations partially mediate the relationship between children's school savings and college progress (i.e., currently attending or already graduated). Bootstrapping confirms this finding.

In study three, Elliott, Kim, Jung, and Zhan (2010) use PSID/CDS data $(\mathrm{N}=1063)$ to test whether mediation effects vary by race (White/Black). Separate samples of White $(\mathrm{N}=$ $576)$ and Black $(\mathrm{N}=487)$ youth are analyzed. They correct for missing data with the Yuan and Bentler (2000) correction for non-normality data with missing data. The Jamshidian and Bentler (1999) method allows a model to be estimated without imputation and loss of subjects. The Yuan and Bentler (2000) correction is similar to Satorra and Bentler (1994) with complete data. Using Structural Equation Modeling (SEM) and bootstrapping, they find that school savings is significantly related to expectations for both White and Black youth. In the case of math, they find that net worth and school savings have indirect effects through college expectations for White youth only (i.e., expectations mediate the relationship between assets and math achievement). In the case of reading, they find that there are no indirect effects regardless of race.
In study four, Elliott, Choi, et al. (2011) conduct a simultaneous test of whether children's savings predict children's college expectations or college expectations predict children's savings. They correct for missing data in a similar fashion as Elliott, Kim, Jung, and Zhan (2010) do. They find that children's savings has a slightly stronger relationship with children's expectations than children's expectations has with savings. However, they suggest that the best interpretation of the data is that two-way causation exists.

In sum, the potential for multiple effects may make policies that seek to build assets among children particularly alluring. Further, findings of two-way causation suggest that assetbuilding policies that seek to build both children's savings along with children's college-bound identity may be most effective at increasing the number of children who have savings and their college outcomes.

\section{Conceptual Framework}

To understand how a college-bound identity is formed, reinforced, and influences outcomes, we use Elliott, Choi et al.'s (2011) theory of asset effects. Their theory is grounded in an Identity-Based Motivation (IBM) theory of children's motivation and behavior (for more information on IBM, see Oyserman \& Destin, 2010). Using the IBM framework, Elliott, Choi, et al. (2011) propose that three principal components explain the relation between assets, college-bound identity and motivation: 1) identity salience, 2) congruence with group identity, and 3) interpretation of difficulty. These principles have been shown to be important predictors of children's school behaviors (Oyserman \& Destin, 2010).

Salience captures the idea that children are more likely to work toward a goal when images of their own future are on their mind. People pay attention to things that they believe are the causes of things that matter to them. As mentioned in the introduction, Elliott, Sherraden, et al. (2010) find that children see savings as a way to pay for college. Another way of stating this finding is that owning savings may be seen as a cause of being able to attend college. As such, owning savings may help make college more salient.

Another important factor in the connection between context, college-bound identity, and behavior is a link to group identity. Congruence with group identity occurs when an image of the self feels tied to ideas about relevant social groups such as friends, classmates, family, and cultural groups. When this occurs, the congruent personal identity is reinforced. Elliott, Choi, et al. (2011) point out that assets are almost always connected to the family. For example, when children open an account they are supported by parents or other family members. Further, parents are often a primary source of children's income through gifts or allowances, for example. As Elliott, Choi, et al. (2011) state, "When children and their families save money for college, the meta-message asserts 'we save,' 'we go to college,' reinforcing the college-bound identity through its congruence with the actions and goals of the larger group" (p. 1105).

Finally, IBM highlights the importance of having a means for positively interpreting and overcoming difficulty. From this perspective, in order for children to sustain effort and work towards an image of themselves as being college-bound, the context must provide a way to address inevitable obstacles to the goal of attending college, such as being able to pay for college. It is clear how having savings provides children with a strategy for paying for college.

This paper builds on previous research in several important 
ways. A way that it builds on previous research is by using propensity score analyses (PSA). PSA is a relatively new statistical method for testing causal inferences using survey data (Rubin, 1996). PSA allows researchers to balance potential bias between those children, for example, who are exposed to having savings and those who are not based on known covariates (Rosenbaum \& Rubin, 1983). While most previous research examining the relationship between assets and children's educational outcomes uses survey data, no study uses PSA. Until recently, propensity score methods have been limited to two-group situations such as a single treatment and a compareson group. However, Imbens (2000) extends the method to multi-group situations (also see Guo \& Fraser, 2010).

Because of these methodological advancements, we are able to build on past research by examining whether asset-building interventions that seek to build both children's savings and a positive college-bound identity, are more likely to be related to children attending college than interventions that only build children's savings or those that only build children's collegebound identities. Specifically we hypothesize that the combined treatment of school savings and positive college-bound identity (i.e., having school savings and being certain they would graduate from a four-year college) is more likely to be associated with children being on course than school savings only treatment (having school savings and being uncertain they would graduate from a four-year college) or college-bound identity-only treatment (being certain they would graduate from a four-year college and not having school savings).

\section{Methods}

\section{Data}

This study uses longitudinal data from the PSID and its supplements, the Child Development Supplement (CDS) and the Transition into Adulthood supplement (TA). The PSID is a nationally representative longitudinal survey of U.S. individuals and families that began in 1968. The PSID collects data on such things as employment, income, and assets. Our independent variables related to households and parents are taken from 1999, 2001, and 2002 PSID data.

The CDS was administered to 3563 PSID respondents in 1997 to collect a wide range of data on parents and their children, aged birth to 12 years. Questions cover a broad range of developmental outcomes across the domains of health, psychological well-being, social relationships, cognitive development, achievement, motivation, and education. Follow-up surveys are administered in 2002 and 2007. For this study, independent variables for young adults are taken from the 2002 CDS because this is the first year data are collected on parents' school savings for youth and youth's school savings. Age 12 is the first year that youth are asked questions about savings and college expectations. The TA supplement, administered in 2005 and 2007, measures outcomes for young adults who participated in earlier waves of the CDS and are no longer in high school. Our outcome variables are taken from the 2007 TA.

The three data sets are linked using PSID, CDS, and TA map files containing family and personal ID numbers. The linked data sets provide a rich opportunity for analyses in which data collected at one point in time (2001 or earlier) can be used to predict outcomes at a later point in time (2007), and stable background characteristics can be used as covariates. Because the PSID initially oversampled low-income families, both the descriptive and multivariate analyses are weighted using the last observed weight variable as recommended by the PSID manual (Gouskova, 2001).

\section{Variables}

There are two variables of interest in this study - children's college expectations and children's savings. Children's college expectations are created using 2002 CDS data. In the CDS, children were asked what they thought the chances were that they would graduate from a four-year college. Children responded by saying no chance, some chance (about 50:50), pretty likely, or it will happen. Children who responded that their chances of graduating from a four-year college were $50 \%$ or less were defined as "uncertain."

The children's savings variable is also created using 2002 CDS data. The CDS asks children between the ages of 12 to 18 whether they had a savings or bank account in their name. The children's savings variable divides children into two categories: 1) those who had an account in 2002, and 2) those who did not have account. There are several important differences between the accounts examined in this study and CDA accounts proposed in the ASPIRE act and other popular education accounts such as Coverdell Education Savings Accounts, Uniform Gifts to Minors Act (UGMAs), 529 College Savings Plans run by States, and Roth Individual Retirement Arrangements (IRAs). Popular educational accounts offer their owner's protection from taxation and in some cases an infrastructure that provides such things as direct deposit and match savings to encourage and promote savings. In order not to be taxed, however, savings in these accounts typically cannot be withdrawn without penalty until youth reach college age and it must be spent on college related expenses. As a result, these accounts can more aptly be defined as being non-liquid in nature. Unlike in these popular education accounts, children can easily withdraw money from the accounts in this study and use that money without penalty but they do not benefit from tax breaks or other incentives that are common components of CDAs (such as initial deposits or match saving where for every dollar a child saves the federal government or other agency matches it with an additional dollar).

Using children's expectations and children's savings variables, we create four treatment groups or doses similar to Imbens (2000) multiple dose treatment approach. The first dose is children who have no savings and are uncertain whether they will graduate from a four-year college. The comparison group in this sample is children with savings only, children who are certain only, and children who both have savings and are certain. The second dose is children who have saving only. The comparison group is children with no savings and who are uncertain, children who are certain only, and children who both have savings and are certain. The third dose is children who are certain only. The comparison group is children with no savings and who are uncertain, children with savings only, and children who both have savings and are certain. The final dose is children who both have savings and are certain they will graduate from a four-year college. The comparison group is children with no savings and who are uncertain, children with savings only, and children who are certain only.

Outcome Variable. The outcome variable combines two variables from the TA. First, youth were asked if they had ever attended college. If they answered yes, they were asked whether they attend or had attended a 2-year college, a four-year college, or graduate school. We created a dichotomous variable indicating whether youth had ever attended a four-year college. These data were collected in 2007. 
Control Variables. There are 15 control variables. They may be thought of as falling into three broad areas: household characteristics, child characteristics, and neighborhood characteristics. Household characteristics consist of family income; net worth; household size; head's education level; head's marital status; and home scale. Child characteristics consist of race, gender, academic achievement, 2002 age, self-efficacy, and self-concept. Neighborhood characteristics consist of urbanicity, private school attendance, and peer expectations.

Family income is calculated by averaging family income for 1993, 1997, and 2002. Income averaged over multiple years provides the best estimate of "permanent income" (Blau, 1999; Mayer, 1997). Income is inflated to 2002 price levels using the Consumer Price Index for 1993 and 1997. Because family income is positively skewed, the log of family income is used in regression analyses.

Net worth. Net worth in the PSID is a continuous variable that sums separate household values for a business, checking or savings accounts, home equity, real estate, stocks, and other assets, and subtracts out credit card and other debt. Net worth is averaged for 1994, 1999, and 2001; each year of net worth is inflated to 2002 price levels. Because net worth is positively skewed, the log form of net worth is used for regression analyses. Since some individuals have a negative value on the net worth variable, it is necessary to make adjustments to these numbers so that the natural log of net worth could be calculated. All net worth values that are less than or equal to 0 are re-coded as 1 so that the natural log could be ascertained (e.g., Henretta \& Campbell, 1978; Orr, 2003).

Household size, head's marital status, and head's education all came from the 2001 PSID. Household size is a continuous variable. Head's marital status is a categorical variable (married or unmarried). Head's education is a continuous variable ( 1 to 16), with each number representing a year of completed schooling. We also use a categorical variable, dividing heads into three groups: those with a high school degree or less, those with some college, and those with a four-year degree or more.

Home scale. The Home Observation for Measurement of the Environment-Short Form from the Caldwell and Bradley HOME Inventory (Caldwell \& Bradley, 1984) is used as a measure of the cognitive stimulation and emotional support parents provide to children. The particular items used in the PSID Child Development Supplement were taken directly from the National Longitudinal Survey of Youth, Mother-Child Supplement so that the scales would be as similar as possible (Baker, Keck, Mott, \& Quinlan, 1993). It includes the following items: how often the child gets out of the house, how many books the child has read, how often the mother takes the child to grocery store, how many cuddly or role-playing toys the child has, the mother's belief about how the child learns best, how many push or pull toys the child has, how often the mother talks to the child while working, and how often the mother reads to the child.

Children's race (White or Black), gender (male or female), age, self-efficacy, self-concept, academic achievement, peer expectations, and private school attendance come from 2002 CDS data.

Academic achievement. This variable is continuous, a combination of math and reading scores. The Woodcock Johnson (WJ-R), a well-respected measure, is used by the CDS to assess math and reading ability (Mainieri, 2006). In descriptive analy-

${ }^{4}$ For more information on the scale go to: http://www.ers.usda.gov/ Briefing/Rurality/RuralUrbCon/. sis, we use a dichotomous variable indicating whether children have average or above-average achievement or below-average achievement. Average or above average is coded 1 and below average is coded as 0 . Age in 2002 is a continuous variable. In the descriptive analysis, we use a dichotomous variable indicating whether children were below or at age 16 or older in 2002 . Below or at age 16 is coded 0 and older than 16 is coded 1 .

Children's self-efficacy. This variable is measured using Pearlin's self-efficacy scale (for information, see Pearlin, Menaghan, Lieberman, \& Mullan, 1981). According to Mainieri (2006), the children's self-efficacy scale measures the amount of control children perceive they have over their life in the PSID/CDS. For descriptive purposes, the mean score is used to create a dichotomous variable (average or above average self-efficacy and below average self-efficacy).

Children's self-concept. This is a continuous variable measured using Rosenberg's self-esteem scale (for information, see Rosenberg 1986). According to Mainieri (2006), children's self-concept measures the degree of satisfaction one has with herself in the PSID/CDS. For descriptive purposes, the mean score is used to create a dichotomous variable (average or above-average self-esteem and below-average self-esteem).

Urbanicity. The 2003 Rural-urban Continuum Codes form a classification scheme that distinguishes metropolitan counties by size and nonmetropolitan counties by degree of urbanization and proximity to metro areas. ${ }^{4}$ The PSID increases the codes by one (ranges from 1 to 10 ). We collapse it into a three-level variable indicating whether children live in a metropolitan, urban, or rural area.

Children's peer expectations. Children are asked how many of their friends planned to attend college: 1) None, 2) a few, 3 ) some, 4) many, and 5) almost all or all. Peer expectations are recoded into a dichotomous variable. If children respond by selecting 1,2 , or 3 , they are coded as 0 ; if they select options 4 or 5 , they are coded as 1 .

Private school attendance. In 2002, children are asked whether they have ever attended private school (yes or no).

\section{Study Sample}

The 2007 TA sample consisted of 1118 participants. The sample in this study is restricted to Black and White youth because only small numbers of other racial groups exist in the TA. Our final sample consisted of 1,003 children and their families. Four separate samples are created based on the dosage being investigated. Table 1 provides the percent in each treatment dose and its comparison group before and after weighting the sample using propensity score weighting. After weighting the treatment and comparison groups were more balanced between the treatment doses (i.e., no savings/uncertain, savings only, certain only, and combined). For example, prior to weighting there was a $26 \%$ gap between the non-savings/uncertain to graduate treatment dose and the combination treatment dose; however, after weighting, there was a $7 \%$ gap between the lowest and highest dose.

Source: Weighted data from the Panel Study of Income Dynamics and its supplements.

Notes: Estimates are propensity score-adjusted using the weighting scheme in Guo \& Fraser, 2010 (also see Foster, 2003; Imbens, 2000). The propensity score weights are based on the propensity scores (or predicted probabilities) calculated using the results of the multinomial logit model. The term certain identifies children who expected to graduate from a four-year college prior to leaving high school. 
Table 1 .

The percent of the sample in each treatment dose and comparison group before and after adjusting for propensity score weight.

\begin{tabular}{lcc}
\hline \multicolumn{1}{c}{ Group } & \% Before Adjustment & \% After Adjustment \\
\hline No savings/uncertain to graduate dose & 17 & 22 \\
Comparison (savings only; certain only and combined) & 83 & 78 \\
Savings only dose & 17 & 24 \\
Comparison (no savings/uncertain; certain only and combined) & 83 & 76 \\
Certain to graduate only dose & 24 & 25 \\
Comparison (no savings/uncertain; savings only and combined) & 76 & 75 \\
Combination dose & 43 & 29 \\
Comparison (no savings/uncertain; savings only and certain only) & 57 & 71 \\
\hline
\end{tabular}

\section{Analysis Plan}

Primarily analyses were conducted using STATA version 10 (STATA Corp, College Station, TX). ${ }^{5}$ There were four stages of analysis conducted in this study. In stage one of the analyses; we completed missing data using multiple imputations. Missing data can lead to inaccurate parameter estimates and biased standard errors and population means, resulting in researchers inaccurately reporting statistical significance or insignificance (Graham, Taylor, \& Cumsille, 2001). In this study, there was less than $1 \%$ missing data on college attendance. However, data for some control variables were also missing. For example, both children's savings and children's college expectations had about $20 \%$ missing. A rule of thumb for how much data can be imputed is about $20 \%$ (Little \& Rubin, 2002). We used the chained equation method of multiple imputations (Royston, 2004, 2005a, b; van Buuren et al., 2006) to create five independent data sets that included all continuous and categorical variables with no missing data. This method allowed us to specify the multivariate structure as a series of imputation models based on other variables. Logistic regression was used to impute the incomplete categorical variables, and linear regression was used to impute continuous variables. Each missing value was filled in with a set of plausible values that were created with information from other values of a variable and some associated variables.

In stage two, we conducted propensity score weighting with multi-treatments/dosages in order to balance selection bias between those children; for example, those who were exposed to having savings and those who were not based on known covariates (Guo \& Fraser, 2010; Imbens, 2000). More specifically, in stage two of the analysis, we created four groups: 1) had no school savings and uncertain they would graduate from a four-year college prior to leaving high school; 2) had school savings and were uncertain they would graduate from a four-year college prior to leaving high school; 3) certain they would graduate from a four-year college and had no school savings prior to leaving high school; and 4) had school savings and were certain they would graduate from a four-year college prior to leaving high school. Next we estimated a multinomial logit regression predicting multi-group membership using 13 of the 15 covariates included in this paper. The only variables included in the multinomial logit regression were those positively correlated following Guo and Fraser's (2010) approach. Household size and urbanicity were not included in creating the propensity score weight or further analyses because they did not have a significant association with college attendance at the ${ }^{5}$ Covariate balance checking is conducted using SAS (SAS Institute Inc., 2008). bivariate level. The resulting coefficient estimates were used to calculate propensity scores for each group. The inverse of that probability was used to create the propensity score weight.

In stage three, we test covariate imbalance after weighting. Since propensity score weighting does not use matching, we run a weighted simple logistic regression using college attendance (i.e., a dichotomous covariate) as the dependent variable, and one of the dichotomous dosage variables (i.e., either no savings/uncertain; savings only, certain only, or combined) as the single independent variable (Guo \& Fraser, 2010). Results from simple logistic regressions are reported in Appendix A and $\mathrm{B}$ along with frequencies or means depending on whether it is a continuous covariate or categorical covariate. Appendix A reports information on all covariates before matching, Appendix B reports information after weighting.

In stage four, we used logistic regression as the primary analytic tool to assess statistical significance for the overall relationship between each dose separately and college attendance without and with propensity score weights included. Moreover, we provided measures of predictive accuracy through the McFadden's pseudo $R^{2}$ (not equivalent to the variance explained in multiple regression model, but closer to 1 is also positive). We also reported odds ratios (OR) for easier interpretation. The odds ratio is a measure of effect size, describing the strength of association. Identical analyses were repeated for all five imputed data sets with no missing data, and the results were pooled (i.e., calculated an average for the five imputed data sets) to yield less biased parameter estimates in the overall regression model. This method is superior to other kinds of imputation methods, such as mean substitution, hot decking, regression imputation, and single imputation, in terms of producing more accurate estimates (Little \& Rubin, 2000; Rubin, 1996).

\section{Results}

In the first part of this section we discuss findings from the covariate balance checks. Then we report logistic regression results for each treatment group.

\section{Bivariate Results from Covariate Balance Checks}

Results from the balance checks are presented in see Appendix A, B. In the unadjusted sample, almost all covariates showed significant group differences regardless of the treatment dose. Once propensity score weighting was conducted, group differences were no longer significant in almost all cases. This suggests that weighting was successful in reducing bias among observed covariates in almost all cases. 


\section{Logit Results for No Savings/Uncertain Treatment Group}

Table 2 provides information on unadjusted and adjusted logit models examining the relationship between the no savings/uncertain treatment group and whether children had ever attended college by 2007 . Approximately $26 \%$ of the variance in college attendance is explained in the adjusted model. Head's education level, household net worth, and children's academic achievement are all statistically significant positive predictors of college attendance among the no savings/uncertain sample of children in the adjusted model.

The no savings/uncertain treatment group is not statistically significant when compared to children with savings only, chil- dren who are certain only, and children who both have savings and are certain while controlling for all other variables.

\section{Logit Results for the Savings Only Treatment Group}

Table 3 provides information on unadjusted and adjusted logit models examining the relationship between the savings-only treatment group and whether children have ever attended college. The adjusted model explains about $25 \%$ of the variance in college attendance. Head's education level, parent's college expectations, household net worth, and children's academic achievement are positive statistically significant predicttors among the sample of children with savings only. Self-efficacy is a negative predictor of college attendance.

Table 2 .

Logit examining the relationship between no savings and no expectations treatment group and college attendance in $2007(N=1003)$.

\begin{tabular}{|c|c|c|c|c|}
\hline \multirow[t]{2}{*}{ Covariates } & \multicolumn{2}{|c|}{$\begin{array}{c}\text { Unadjusted } \\
\text { No Savings/Uncertain Treatment }\end{array}$} & \multicolumn{2}{|c|}{$\begin{array}{c}\text { Adjusted } \\
\text { No Savings/Uncertain Treatment }\end{array}$} \\
\hline & $B$ & S.E. & B & S.E. \\
\hline No savings/uncertain treatment & -0.409 & 0.230 & -0.738 & 0.357 \\
\hline Home scale & 0.970 & 0.517 & 0.545 & 0.830 \\
\hline Head's education level & $0.161 * *$ & 0.046 & $0.285^{*}$ & 0.080 \\
\hline $\begin{array}{l}\text { Head's marital status } \\
\text { Parent's college expectations for their child } \\
\text { Household net worth }\end{array}$ & $\begin{array}{c}0.661^{* *} \\
1.605^{* * *} \\
0.071^{* *}\end{array}$ & $\begin{array}{l}0.195 \\
0.190 \\
0.023\end{array}$ & $\begin{array}{c}0.522 \\
1.447 \\
0.076^{*}\end{array}$ & $\begin{array}{l}0.286 \\
0.255 \\
0.029\end{array}$ \\
\hline Household income & -0.043 & 0.028 & -0.050 & 0.043 \\
\hline Child's race & 0.305 & 0.212 & 0.367 & 0.320 \\
\hline Child's age in 2002 & 0.033 & 0.054 & 0.154 & 0.087 \\
\hline Child's self-efficacy & -0.261 & 0.171 & -0.558 & 0.241 \\
\hline Child's self-concept & 0.363 & 0.236 & 0.152 & 0.315 \\
\hline Child's academic achievement & $0.023 * * *$ & 0.004 & $0.014^{*}$ & 0.006 \\
\hline Child's college expectations for peers & $0.597 * *$ & 0.191 & 0.265 & 0.256 \\
\hline $\begin{array}{l}\text { Whether child ever attended private school } \\
\text { McFadden pseudo } R^{2}\end{array}$ & 0.560 & 0.449 & -1.067 & $\begin{array}{r}0.919 \\
.26\end{array}$ \\
\hline
\end{tabular}

Source: Weighted data from the Panel Study of Income Dynamics and its supplements. Notes: Data imputed using multiple imputations. S.E. = robust standard error. O.R. $=$ odds ratio. Estimates are propensity score-adjusted using the weighting scheme in Guo \& Fraser, 2010 (also see Foster, 2003 and Imbens, 2000 ). The propensity score weights are based on the propensity scores (or predicted probabilities) calculated using the results of the multinomial logit model. * $p<.05 ; * * p<.01 ; * * *<.001$.

Table 3.

Logit examining the relationship between the savings only treatment group and college attendance in $2007(N=1003)$.

\begin{tabular}{|c|c|c|c|c|c|}
\hline \multirow[t]{2}{*}{ Covariates } & \multicolumn{2}{|c|}{$\begin{array}{c}\text { Unadjusted } \\
\text { Savings Only Treatment }\end{array}$} & \multicolumn{3}{|c|}{$\begin{array}{c}\text { Adjusted } \\
\text { Savings Only Treatment }\end{array}$} \\
\hline & $B$ & S.E. & $B$ & S.E. & \\
\hline Savings only treatment & $-0.535^{*}$ & 0.231 & -0.600 & 0.322 & \\
\hline Home scale & $1.121^{*}$ & 0.515 & 0.887 & 0.838 & \\
\hline Head's education level & $0.168 * * *$ & 0.046 & $0.285^{* *}$ & 0.076 & \\
\hline Head's marital status & $0.679 * *$ & 0.195 & 0.423 & 0.305 & \\
\hline Parent's college expectations for their child & $1.613^{* * *}$ & 0.190 & $1.487 * * *$ & 0.253 & \\
\hline Household net worth & $0.072 * *$ & 0.023 & $0.072 *$ & 0.030 & \\
\hline Household income & -0.040 & 0.028 & -0.040 & 0.047 & \\
\hline Child's race & 0.203 & 0.216 & 0.263 & 0.346 & \\
\hline Child's age in 2002 & 0.060 & 0.055 & 0.137 & 0.086 & \\
\hline Child's self-efficacy & -0.255 & 0.170 & $-0.600 *$ & 0.252 & \\
\hline Child's self-concept & 0.401 & 0.235 & 0.270 & 0.305 & \\
\hline Child's academic achievement & $0.023^{* * *}$ & 0.004 & $0.014^{*}$ & 0.006 & \\
\hline Child's college expectations for peers & $0.614^{* *}$ & 0.189 & 0.189 & 0.268 & \\
\hline $\begin{array}{l}\text { Whether child ever attended private school } \\
\text { McFadden pseudo } R^{2}\end{array}$ & 0.573 & 0.454 & -0.845 & 0.870 & .25 \\
\hline
\end{tabular}

Source: Weighted data from the Panel Study of Income Dynamics and its supplements. Notes: Data imputed using multiple imputations. S.E. = robust standard error. O.R. $=$ odds ratio. Estimates are propensity score-adjusted using the weighting scheme in Guo \& Fraser, 2010 (also see Foster, 2003 and Imbens, 2000 ). The propensity score weights are based on the propensity scores (or predicted probabilities) calculated using the results of the multinomial logit model. * $p<.05 ; * * p<.01 ; * * *<.001$. 
The savings only treatment group is not statistically significant when compared to children with no savings and who are uncertain, children who are certain only, and children who both have savings and are certain while controlling for all other variables.

\section{Logit Results for the Certain Only Treatment Group}

Table 4 provides information on the unadjusted and adjusted logit models examining the relationship between the certainonly treatment group and college attendance. The certain-only treatment group sample consists of children who expected to graduate from a four-year college prior to leaving high school. The adjusted model explains about $27 \%$ of the variance in college attendance. Similar to Table 3, head's education level, parent's college expectations, household net worth, and children's academic achievement are all positive statistically significant predictors of children in the certain-only treatment group while self-efficacy is a negative predictor.

The certain-only treatment group is not statistically signifi- cant when compared to children with no savings and who are uncertain, children with savings only, and children who both have savings and are certain while controlling for all other variables.

\section{Logit Results for the Combined Treatment Group}

Table 5 provides information on unadjusted and adjusted logit models examining the relationship between the combined treatment group (i.e., have savings and are certain they will graduate from a four-year college) and whether children have ever attended college by 2007 . Approximately $26 \%$ of the variance in college attendance is explained in the adjusted model. Head's education level, parent's college expectations, household net worth, and children's academic achievement are all statistically significant positive predictors of children with savings and who are certain they will graduate from a four-year college, while self-efficacy is a negative predictor of college attendance.

Unlike the other treatment groups, the combined treatment

Table 4.

Logit examining the relationship between the certain only treatment group and college attendance in $2007(N=1003)$.

\begin{tabular}{|c|c|c|c|c|}
\hline \multirow{2}{*}{ Covariates } & \multicolumn{2}{|c|}{$\begin{array}{c}\text { Unadjusted } \\
\text { Certain Only Treatment }\end{array}$} & \multicolumn{2}{|c|}{$\begin{array}{c}\text { Adjusted } \\
\text { Certain Only Treatment }\end{array}$} \\
\hline & $B$ & S.E. & $B$ & S.E. \\
\hline Certain only treatment & -0.001 & 0.102 & 0.174 & 0.127 \\
\hline Home scale & $1.091 *$ & 0.512 & 0.730 & 0.824 \\
\hline Head's education level & $0.163 * *$ & 0.046 & $0.285^{* *}$ & 0.076 \\
\hline Head's marital status & $0.663 * *$ & 0.195 & 0.454 & 0.300 \\
\hline Parent's college expectations for their child & $1.641^{* * *}$ & 0.189 & $1.444 * * *$ & 0.250 \\
\hline Household net worth & $0.075 * *$ & 0.022 & $0.071^{*}$ & 0.030 \\
\hline Household income & -0.042 & 0.028 & -0.043 & 0.047 \\
\hline Child's race & 0.311 & 0.216 & 0.325 & 0.338 \\
\hline Child's age in 2002 & 0.036 & 0.054 & 0.141 & 0.085 \\
\hline Child's self-efficacy & -0.267 & 0.170 & $-0.619 *$ & 0.248 \\
\hline Child's self-concept & 0.388 & 0.234 & 0.261 & 0.299 \\
\hline Child's academic achievement & $0.024 * * *$ & 0.004 & $0.014 *$ & 0.006 \\
\hline Child's college expectations for peers & $0.645 * *$ & 0.188 & 0.213 & 0.267 \\
\hline Whether child ever attended private school & 0.605 & 0.450 & -0.960 & 0.904 \\
\hline McFadden pseudo $R^{2}$ & & & & .27 \\
\hline
\end{tabular}

Source: Weighted data from the Panel Study of Income Dynamics and its supplements. Notes: Data imputed using multiple imputations. S.E. = robust standard error. O.R. $=$ odds ratio. Estimates are propensity score-adjusted using the weighting scheme in Guo \& Fraser, 2010 (also see Foster, 2003 and Imbens, 2000 ). The propensity score weights are based on the propensity scores (or predicted probabilities) calculated using the results of the multinomial logit model. * $p<.05 ; * * p<.01 ; * * *<.001$.

Table 5.

Logit examining the impact relationship between the combined treatment group and college attendance in $2007(N=1003)$.

\begin{tabular}{|c|c|c|c|c|c|}
\hline \multirow{2}{*}{ Covariates } & \multicolumn{2}{|c|}{$\begin{array}{c}\text { Unadjusted } \\
\text { Combined Treatment }\end{array}$} & \multicolumn{3}{|c|}{$\begin{array}{c}\text { Adjusted } \\
\text { Combined Treatment }\end{array}$} \\
\hline & $B$ & S.E. & $B$ & S.E. & \\
\hline Combined treatment & $0.251 * * *$ & 0.072 & $0.276^{* *}$ & 0.081 & \\
\hline Home scale & 0.922 & 0.589 & 0.687 & 0.824 & \\
\hline Head's education level & $0.151 * *$ & 0.052 & $0.285^{* *}$ & 0.081 & \\
\hline Head's marital status & $0.662 * *$ & 0.218 & 0.485 & 0.301 & \\
\hline Household net worth & $0.065^{* *}$ & 0.024 & $0.079^{*}$ & 0.029 & \\
\hline Household income & -0.043 & 0.031 & -0.047 & 0.044 & \\
\hline Child's race & 0.313 & 0.238 & 0.270 & 0.340 & \\
\hline Child's age in 2002 & 0.032 & 0.060 & 0.152 & 0.088 & \\
\hline Child's self-efficacy & -0.244 & 0.185 & $-0.523^{*}$ & 0.247 & \\
\hline Child's self-concept & 0.369 & 0.253 & 0.169 & 0.311 & \\
\hline Child's academic achievement & $0.022 * * *$ & 0.004 & $0.014 *$ & 0.006 & \\
\hline Child's college expectations for peers & $0.547^{*}$ & 0.206 & 0.237 & 0.266 & \\
\hline
\end{tabular}

Source: Weighted data from the Panel Study of Income Dynamics and its supplements. Notes: Data imputed using multiple imputations. S.E. = robust standard error. O.R. $=$ odds ratio. Estimates are propensity score-adjusted using the weighting scheme in Guo \& Fraser, 2010 (also see Foster, 2003 and Imbens, 2000 ). The propensity score weights are based on the propensity scores (or predicted probabilities) calculated using the results of the multinomial logit model. ${ }^{*} p<.05 ; * * p<.01 ; * * p<.001$. 
group has a statistically significant positive association with college attendance when compared to children with no savings and who are uncertain, children with savings only, and children who are certain only after controlling for all other covariates.

In sum, head's education level, parent's college expectations, household net worth, children's academic achievement, and child's self-efficacy are all significant predictors of college attendance among all treatment groups except for the no savings/uncertain treatment group. Only self-efficacy is a negative predictor of college attendance. Further, among the four treatment groups, only the combined treatment group is a significant predictor of college attendance.

\section{Discussion}

Rising college costs have led to fewer low- and moderate-income children attending and graduating from college in an era when college graduation is increasingly important to career success. CDAs have been proposed as a potentially novel and promising mechanism for reducing college costs and encouraging college attendance. Previous research suggests that children's asset-building programs may be enhanced if they are combined with strategies to build children's college-bound identity (e.g., Elliott \& Beverly, 2011b; Elliott, Choi, et al. 2011). In this study we examine whether children who have savings and who are certain they will graduate from a four-year college (i.e., a proxy for college-bound identity) are more likely to attend college shortly after graduating high school than children who do not have savings and who are uncertain, children who have savings but are uncertain, and children who are certain but do not have savings.

Similar to Elliott and Beverly (2011b) who find that children's savings is associated with college attendance among a sample of children who expect to graduate from a four-year college, we find that the combined treatment group is a significant predictor of college attendance. In regards to household net worth, previous research suggests that net worth is a significant predictor of college attendance but only when children's academic achievement or children's cognitive ability is not included (e.g., Conley, 2001; Jez, 2008; Nam \& Huang, 2009). In contrast, controlling for children's academic achievement, we find that net worth is a significant predictor in all four treatment groups. The reason for the different findings may be because we use very different samples than previous research.

Consistent with previous research (e.g., Stratton, O'Toole, \& Wetzel, 2007), parent's education level and children's academic achievement remain statistically significant predictors of whether children attend college. Parent's college expectations for their child are also a significant positive predictor of college attendance for all treatment groups except for the no savings/uncertain treatment group. This too is consistent with previous research on college attendance (e.g., William Shanks \& Destin, 2009).

Surprisingly, self-efficacy is a negative predictor in all treatment groups except for the no savings/uncertain treatment group where it is not significant. Self-efficacy is usually thought of as being a positive predictor of children's academic outcomes (e.g., Bandura, 1997). A reason for the negative findings may be because the self-efficacy scale used in this study measures children's global self-efficacy (e.g., "I can make things happen").

${ }^{6}$ For more information on SEED OK, see http://csd.wustl.edu/AssetBuilding/SEEDOK/

${ }^{7}$ See Elliott, Choi, et al. (2011) for more information on how IBM can be used to explain asset effects.
However, Bandura (1997) suggests that in order to accurately predict academic outcomes, self-efficacy “... beliefs should be measured in terms of particularized judgments of capability" ( $p$. 42). An example of a more particularized judgment is "I can make things happen in reading class."

\section{Limitations}

Propensity score analyses have two clear disadvantages relative to randomized trials. One is the need to assume conditional independence (i.e., selection bias is eliminated by controlling for observed covariates). This may not be true as it is impossible to know all the covariates that may influence the choice to participate in treatment. The precision of controlling for treatment choice goes as far as the covariates included in the study. In randomized trials, the researcher can be confident that the treatment group and the control group are similar on both observed and unobserved characteristics. Second, whereas propensity score analyses can only estimate treatment effects where there is overlap between exposed group (e.g., group that has savings) and unexposed group (e.g., does not have savings), random assignment ensures that there is common support across the whole sample. These considerations make experimental techniques superior to propensity score analyses in a number of important ways.

However, randomization also has its limitations. A practical limitation is cost. Cost is a major concern with designing random control trials to test CDAs. Providing children with initial deposits and matches (i.e., every one dollar saved is matched with an additional dollar) can be expensive. Another concern is time. CDAs that are in the state's name with the youth as the beneficiary are being tested in a large experiment in Oklahoma called SEED for Oklahoma Kids (SEED OK). ${ }^{6}$ However, because the accounts were issued at birth in 2004 , it will be a number of years before researchers can test this design as it relates to college progress. In the meantime, CDAs have already been proposed in Congress and policymakers are forced to make decisions sooner rather than later on their value as a mechanism for increasing rates of college progress. Providing policymakers with information now is of the utmost importance, as is using the best available data and methods.

Lastly, Destin and Oyserman (2010) suggest that education-dependent identity (i.e., children expect to get a job that requires a degree) may be a better predictor of children's true college expectations than the measure used in this study (i.e., no chance, some chance (about 50:50), pretty likely, or it will happen). Future research may want to examine whether education-dependent identity is a better measure of children's college expectations.

\section{Implications}

Overall, findings from this study suggest that a way to increase college attendance rates is to create education policies that will both increase children's savings along with a more positive college-bound identity. CDAs are a policy mechanism for promoting children's savings. However, CDA programs proposed in the ASPIRE Act have not attempted to incorporate strategies for building a more positive college-bound identity. We suggest that a way that CDAs can be designed to help build children's college-bound identities is by incorporating Identity Based Motivation (IBM) strategies into the financial education component of CDA policies. IBM assumes that people's perceptions of their possible selves are dynamically constructed in context. $^{7}$

Possible selves programs can be designed to increase student 
motivation by having students examine their future and think about goals that are important to them for attending college. There are many ways that the financial education curricula in existing CDA policies could be adapted to have students examine their future and think about goals that are important to them for attending college. For example, financial education curriculums could be designed to also teach children about the cost of college, about financial aid, and the role savings can play in meeting college costs. In this manner, children are being taught strategies to overcome a perceived difficulty (i.e., ability to pay for college) related to college attendance. According to IBM, in order to sustain and work towards an image of a future self (such as a college-bound identity), the context must provide a way to address inevitable obstacles to the goal such as paying for college (Elliott, Choi, et al. 2011). Further, they could be taught about how much they can expect to save by earning incentives, initial deposits, match savings (i.e., for every dollar saved an additional dollar is placed in the child's account up to a certain amount each year), and interest, for example.

Policies that seek to increase parent's college expectations for their child may also be a particularly promising strategy for increasing children's college attendance rates. When elements of a family's environment contain cues about assets, like parents' savings accounts, the presence of such resources can bolster parents' expectations for their children, influencing both their own interactions with children and children's own college expectations and school-related behaviors. Children's savings as proposed in the ASPIRE Act may be a way to positively influence parent expectations and build congruence with group identity, a key component of an IBM theory of college-bound identity. IBM suggests that when an image of the self feels tied to ideas about relevant social groups (such as, friends, classmates, family and cultural groups), the congruent personal identity becomes reinforced. As Loke and Sherraden (2009) suggest, CDAs may have a multiplier effect by engaging the larger family in the asset-accumulation process. A way that this may happen in CDAs is by allowing parents to make voluntary after-tax contributions into children's accounts.

\section{Conclusion}

A clear implication of this study is that when children have savings and have a positive college-bound identity they are more likely to attend college than both children who have savings but are uncertain that they will graduate from college, and children who are certain they will graduate from college but have no savings. Given this, policies that seek to build both children's savings and more positive college-bound identities are likely to be more successful at increasing college attendance than those that only promote savings or only promote a positive college-bound identity.

\section{References}

ACSFA (2010). The rising price of inequality: How inadequate grant aid limits college access and persistence. Washington, DC: Advisory Committee on Student Financial Assistance.

Baker, P., Keck, C., Mott, F., \& Quinlan, S. (1993). NLSY child handbook revised edition: A guide to the 1986-1990 national longitudinal survey of youth child data. Columbus, $\mathrm{OH}$ : Center for Human Resource Research.

Bandura, A. (1997). Self-efficacy: The exercise of control. New York: W.H. Freeman.

Baron, R. M., \& Kenny, D. A. (1986). The moderator-mediator variable distinction in social psychological research: Conceptual, strategic, and statistical considerations. Journal of Personality and Social Psychology, 51, 1173-1182. doi:10.1037/0022-3514.51.6.1173

Baum, S., Ma, J., \& Payea, K. (2010). Education pays 2010: The benefits of higher education for individual and society. New York, NY: CollegeBoard.

Belk, R. W. (1988). Possessions and the extended self. The Journal of Consumer Research, 15, 139-168. doi:10.1086/209154

Blau, D. M. (1999). The effect of income on child development. The Review of Economics and Statistics, 81, 261-276. doi: $10.1162 / 003465399558067$

Brown, W. G., Chingos, M., et al. (2009). Crossing the finish line: Completing college at America's public universities. Princeton, NJ, Princeton University Press.

Caldwell, B. M., \& Bradley, R. H. (1984). Home observation for measurement of the environment. Little Rock, AR: University of Arkansas.

Carnevale, A. P., Smith, N., \& Strohl, J. (2010). Help wanted: Projections of jobs and education requirements through 2018. Washington, DC: Georgetown University Center on Education and the Workforce.

Coleman, J., Campbell, E., Hobson, C., McPartland, J., Mood, A., \& Weinfeld, F. D. (1966). Equality of educational opportunity. Washington, DC: Department of Health, Education and Welfare.

Coleman, J. (1988). Social capital in the creation of human capital. The American Journal of Sociology, 94, S95-S120. doi: $10.1086 / 228943$

College Board. (2009). Trends in student aid. Trends in higher education series. Washington, DC: College Board.

Conley, D. (2001). Capital for college: Parental assets and postsecondary schooling. Sociology of Education, 74, 59-72. doi: $10.2307 / 2673145$

Cook, T. D., Church, M. B., et al. (1996). The development of occupational aspirations and expectations among inner-city boys. Child Development, 67, 3368-3385. doi:10.2307/1131783

Dauphin, A., El Lahga, A.-R., et al. (2008). Are children decision-makers within the household (IZA Discussion Papers 3728). Bonn, Germany: Institute for the Study of Labor (IZA).

Destin, M. (2009). Assets, inequality, and the transition to adulthood: An analysis of the Panel Study of Income Dynamics (Issue Brief). New York: The Aspen Institute, Initiative on Financial Security.

Destin, M., \& Oyserman, D. (2009). From assets to school outcomes: How finances shape children's perceived possibilities and intentions. Psychological Science, 20, 414-418.

Destin, M., \& Oyserman, D. (2010). Incentivizing education: Seeing schoolwork as an investment, not a chore. Journal of Experimental Social Psychology. Online First.

Elliott, W. (2009). Children's college aspirations and expectations: The potential role of college

development accounts (CDAs). Children and Youth Services Review, 31, 274-283. doi:10.1016/j.childyouth.2008.07.020

Elliott, W. and Beverly, S. (2011). Staying on course: The effects of savings and assets on the college progress of young adults. American Journal of Education, 117), 343-374. doi:10.1086/659211

Elliott, W. and Beverly, S. (2011b). The role of savings and wealth in reducing "wilt" between expectations and college attendance. Journal of Children \& Poverty, 17, 165-185.

Elliott, W., Choi, E. H., Destin, M. and Kim, K. (2011). The age old question, which comes first? A simultaneous test of children's savings and children's college-bound identity. Children \& Youth Services Review, 33, 1101-1111. doi:10.1016/j.childyouth.2011.02.001

Elliott, W., Constance-Huggins, M., \& Song, H.-a. (2011). Factors predicting college progress among low- to moderate-income and high-income young adults: Assets as an understudied form of economic capital (CSD Working Paper 11-15). St. Louis, MO: Washington University, Center for Social Development.

Elliott, W., Destin, M, and Friedline, T. (2011). Taking stock of ten years of research on the relationship between assets and children's educational outcomes: Implications for theory, policy and intervention. Children and Youth Services Review, 33, 2312-2328. doi:10.1016/j.childyouth.2011.08.001

Elliott, W., Kim, K., Jung, H., \& Zhan, M. (2010). Asset holding and educational attainment among African American and Caucasian children. Children and Youth Services Review, 32, 1497-1507. doi:10.1016/j.childyouth.2010.03.019 
Elliott, W., \& Nam, I. (in press). Direct effects of assets and savings on the college progress of black young adults. Educational Evaluation and Policy Analysis.

Elliott, W., Sherraden, M., Johnson, L., \& Guo, B. (2010). Young children's perceptions of college and saving: The potential role of child development accounts. Children and Youth Services Review, 32, 1577-1584. doi:10.1016/j.childyouth.2010.03.018

Executive Office of the President. Office of Management and Budget (2009). Simplifying student aid: The case for an easier, faster, and more accurate FAFSA. Washington, DC: Office of Management and Budget.

Friedline, T., \& Elliott, W. (in press). Predicting savings from adolescence to young adulthood. Journal of the Society for Social Work and Research.

Furby, L. (1978). Possession in humans: An exploratory study of its meaning and motivation. Social Behavior and Personality, 6, 49-64. doi:10.2224/sbp.1978.6.1.49

Furby, L. (1980). The origins and early development of possessive behavior. Political Psychology, 2, 30-42. doi:10.2307/3790969

Gouskova, E. (2001). The 2002 PSID child development supplement (CDS-II) weights. URL (Retrieved 7 August 2010)

http://psidonline.isr.umich.edu/CDS/questionnaires/cdsiiweights.pdf

Graham, J. W., Taylor, B. J., \& Cumsille, P. E. (2001). Planned missing data designs in analysis of change. In L. M. Collins, \& A. Sayer (Eds.), New methods for the analysis of change (pp. 335-353). Washington, DC: American Psychological Association. doi:10.1037/10409-011

Guo, S., \& Fraser, W. M. (2010). Propensity score analysis: Statistical methods and applications. Thousand Oaks, CA, Sage Publications, Inc

Haskins, R. (2008). Education and economic mobility. In J. B. Isaacs, I. V. Sawhill, \& R. Haskins, Getting ahead or losing ground: Economic mobility in America (pp. 91-104). Washington, DC: The Brookings Institution.

Haveman, R., \& Wolff, E. N. (2005). Who are the asset poor? Levels, trends, and composition, 1983-1998. In M. Sherraden (Ed.), Inclusion in the American dream: Assets, poverty, and public policy (pp. 61-86). New York: Oxford University Press.

Heckman, J. J., \& Smith, J. A. (1995). Assessing the case for social experiments. American Economic Association, 9, 85-110.

Henretta, J. C., \& Campbell, R. T. (1978). Net worth as an aspect of status. American Journal of Sociology, 83, 1204-1223. doi:10.1086/226679

Huang, J., Guo, B., et al. (2010). Parental income, assets, borrowing constraints and children's post-secondary education. Children and Youth Services Review, 32, 585-594. doi:10.1016/j.childyouth.2009.12.005

Imbens, G. W. (2000). The role of the propensity score in estimating dose-response functions. Biometrika, 87, 706-710. doi:10.1093/biomet/87.3.706

Jamshidian, M., \& Bentler, P. M. (1999). ML estimation of mean and covariance structures with missing data using complete data routines." Journal of Educational and Behavioral Statistics, 24, 21-41.

Jez, S. J. (2008). The influence of wealth and race in four-year college attendance University of California, Berkeley, Center for Studies in Higher Education.

Levison, D. (2000). Children as economic agents. Feminist Economics, 6, 125-134. doi:10.1080/135457000337732

Little, R. J. A., \& Rubin, D. B. (2002). Statistical analysis with missing data. New York, NY: John Wiley and Sons.

Loke, V., \& Sherraden, M. (2009). Building assets from birth: A global comparison of child development account policies. International Journal of Social Welfare, 18, 119-129. doi:10.1111/j.1468-2397.2008.00605.x

Lu, B., Zanutto, E., Hornik, R., \& Rosenbaum, P. R. (2001). Matching with doses in an observational study of a media campaign against drug abuse. Journal of American Statistical Association, 96, $1245-$ 1253. doi:10.1198/016214501753381896

Mainieri, T. (2006). The panel study of income dynamics child development supplement: User guide for CDS-II. Ann Arbor, MI: University of Michigan, Institute for Social Research.

Marjoribanks, K. (1984). Ethnicity, family environment and adolescents' aspirations: A follow-up study. Journal of Educational Research, 77, 166-171.
Mau, W. C. (1995). Educational planning and academic achievement of middle school students: A racial and cultural comparison. Journal of Counseling and Development, 73, 518-526.

Mayer, S. (1997). What money can't buy: family income and children's life chances. Cambridge, MA: Harvard University Press.

Meeks, C. B. (1998). Factors influencing adolescents' income and expenditures. Journal of Family and Economic Issues, 19, 131-149. doi:10.1023/A:1022948623549

Mickelson, R. A. (1990). The attitude-achievement paradox among black adolescents. Sociology of Education, 63, 44-61. doi: $10.2307 / 2112896$

Nam, Y., \& Huang, J. (2009). Equal opportunity for all? Parental economic resources and children's educational achievement. Children and Youth Services Review, 31, 625-634. doi:10.1016/i.childyouth.2008.12.002

Orr, A. (2003). Black-white differences in achievement: The importance of wealth. Sociology of Education, 76, 281-304. doi: $10.2307 / 1519867$

Oyserman, D., \& Destin, M. (2010). Identity-based motivation: Implications for intervention. The Couseling Psychologist, 38, 1001-1043.

Paulsen, M. B. (2001). The economics of human capital and investment in higher education. In M. B. Paulsen \& J. C. Smart (Eds.), The finance of higher education: Theory, research, policy and practice, pp. 55-94. New York, Agathon Press.

Pearlin, L. J., Menaghan, E. G., et al. (1981). The stress process. Journal of Health and Social Behavior, 22, 337-356. doi: $10.2307 / 2136676$

Porfeli, E., Wang, C., et al. (2009). Influence of social and community capital on student achievement in a large urban school district. Education and Urban Society, 42, 72-95. doi: $10.1177 / 0013124509343373$

Reynolds, J. R. \& Pemberton, J. (2001). Rising college expectations among youth in the United States: A comparison of the 1979 and 1997 NLSY. The Journal of Human Resources, 36, 703-726. doi: $10.2307 / 3069639$

Rosenbaum, P. R., \& Rubin, D. B. (1983). Reducing bias in observational studies using subclassification on the propensity score. Journal of the American Statistical Association, 79, 516-524. doi: $10.2307 / 2288398$

Rosenberg, M. (1986). Conceiving the self. New York, NY, Basic Books.

Royston, P. (2004). Multiple imputation of missing values. Stata Journal, 4, 227-241

Royston, P. (2005a). Multiple imputation of missing values: Update. Stata Journal 5, 188-201.

Royston P. (2005b). Multiple imputation of missing values: Update of ice. Stata Journal, 5, 527-536.

Rubin, D. B. (1996). Multiple imputation after 18+ years. Journal of the American Statistical Association, 91, 474-489. doi: $10.2307 / 2291635$

Rubin, D. B. (2005). Causal inference using potential outcomes: Design, modeling, decisions. Journal of the American Statistical Association, 100, 322-331. doi:10.1198/016214504000001880

SAS Institute Inc. (2008). SAS/STAT® 9.2 User's Guide. URL (Accessed on 5 July 2009)

http://support.sas.com/documentation/cdl/en/statugsurveylogistic/618 36/PDF/default/statugsurveylogistic.pdf.

Sherraden, M. (1990). Stakeholding: notes on the theory of welfare based assets. Social Service Review, 64, 581-601. doi:10.1086/603797

Sherraden, M. (1991). Assets and the poor: A new American welfare policy. Armonk, NY: M.E. Sharpe.

Sirin, S. R. (2005). Socioeconomic status and academic achievement: A meta-analytic review of research. Review of Educational Research, 75, 417-453. doi:10.3102/00346543075003417

STATA. (2009). Survey-Introduction to survey command. URL (Accessed on 9 November 2010) http://www.stata.com/bookstore/pdf/svy survey.pdf

Stratton, L., O'Toole, D., \& Wetzel, J. (2007). Are the factors affecting dropout behavior related to initial enrollment intensity for college undergraduates? Research in Higher Education, 48, 453-485. doi:10.1007/s11162-006-9033-4

van Buuren, S., Brand, J. P. L., Groothiuis-Oudshoorn, C. G., \& Rubin, D. B. (2006). Fully conditional specification in multivariate imputa- 
tion. Journal of Statistical Computation and Simulation, 76, 10491064. doi:10.1080/10629360600810434

Williams Shanks, T., \& Destin, M. (2009). Parental expectations and educational outcomes for young African American adults: Do household assets matter? Race and Social Problems, 1, 27-35. doi:10.1007/s12552-009-9001-7

Yilmazer, T. (2008). Saving for children's college education: An empirical analysis of the trade-off between the quality and quantity of children. Journal of Family and Economic Issues, 29, 307-324.
Zhan, M. (2006). Assets, parental expectations and involvement, and children's educational performance. Children and Youth Services Review, 28, 961-975.

Zhan, M., \& Sherraden, M. (2009). Assets and liabilities, educational expectations, and children's college degree attainment (Working Paper No. 09-60). St. Louis, MO: Washington University, Center for Social Development. 


\section{Appendix A}

Table 1.

Covariate balance in 1003 matched pairs of a no savings/uncertain dose, savings only dose, certain to graduate dose only and combination dose before adjusting for propensity score weight.

\begin{tabular}{|c|c|c|c|c|c|c|c|c|}
\hline \multirow{2}{*}{ Covariates } & \multirow{2}{*}{$\begin{array}{l}\text { No Savings / Uncertain } \\
\text { ( } \% \text { or X) }\end{array}$} & \multirow{2}{*}{$\begin{array}{l}\text { Comparison } \\
\text { (\% or X) }\end{array}$} & \multicolumn{2}{|c|}{ Balance } & \multirow{2}{*}{$\begin{array}{l}\text { No Sav- } \\
\text { ings / } \\
\text { Uncertain } \\
(\% \text { or } X)\end{array}$} & \multirow{2}{*}{$\begin{array}{l}\text { Comparison } \\
(\% \text { or } X)\end{array}$} & \multicolumn{2}{|c|}{ Balance } \\
\hline & & & $\mathrm{B}$ & $\begin{array}{c}\text { Robust } \\
\text { SE }\end{array}$ & & & $\mathrm{B}$ & $\begin{array}{c}\text { Robust } \\
\text { SE }\end{array}$ \\
\hline Home scale & 0.96 & 1.11 & $-0.534 * * *$ & 0.057 & 1.03 & 1.09 & $-0.233 *$ & 0.112 \\
\hline Head's education level & 11.66 & 13.25 & $-0.042 * * *$ & 0.005 & 12.45 & 12.97 & -0.017 & 0.035 \\
\hline Head is married & 48 & 68 & $-0.849 * *$ & 0.172 & 66 & 63 & 0.125 & 0.292 \\
\hline Head is not married & 52 & 32 & & & 34 & 37 & & \\
\hline $\begin{array}{l}\text { Parent expects child to } \\
\text { graduate }\end{array}$ & 19 & 63 & $-1.98 * * *$ & 0.21 & 46 & 54 & -0.318 & 0.329 \\
\hline $\begin{array}{l}\text { Parent does not expect child } \\
\text { to graduate }\end{array}$ & 81 & 37 & & & 54 & 46 & & \\
\hline Household net worth & 7.15 & 9.58 & $-0.019 * * *$ & 0.003 & 8.71 & 8.76 & 0.000 & 0.005 \\
\hline Household income & 8.97 & 9.88 & $-0.012 * *$ & 0.004 & 9.39 & 9.65 & -0.004 & 0.007 \\
\hline Child's race Black & 63 & 43 & $0.805^{* * *}$ & 0.178 & 53 & 47 & 0.265 & 0.320 \\
\hline Child's race White & 37 & 57 & & & 47 & 53 & & \\
\hline Child's age in 2002 & 16.4 & 16.31 & 0.005 & 0.007 & 16.65 & 16.20 & $0.027^{*}$ & 0.013 \\
\hline Child's self-efficacy & 2.96 & 3.08 & $-0.045^{*}$ & 0.02 & 3.05 & 3.04 & 0.003 & 0.189 \\
\hline Child's self-concept & 3.36 & 3.44 & $-0.064 *$ & 0.028 & 3.25 & 3.46 & $-0.157^{*}$ & 0.058 \\
\hline $\begin{array}{l}\text { Child's academic achieve- } \\
\text { ment }\end{array}$ & 187.62 & 209.28 & $-0.003 * * *$ & 0.003 & 199.20 & 206.15 & -0.001 & 0.004 \\
\hline $\begin{array}{l}\text { Expects most/all peers to } \\
\text { graduate from college }\end{array}$ & 45 & 78 & $-1.481^{* * *}$ & 0.177 & 67 & 71 & -3.039 & 0.277 \\
\hline $\begin{array}{l}\text { Does not expect most/all } \\
\text { peers to graduate from } \\
\text { college }\end{array}$ & 55 & 22 & & & 33 & 29 & & \\
\hline Attended private school & 1 & 8 & $-2.01 * *$ & 0.723 & 1 & 11 & $-4.404 *$ & 0.663 \\
\hline $\begin{array}{l}\text { Did not attend private } \\
\text { school }\end{array}$ & 99 & 92 & & & 99 & 89 & & \\
\hline \multirow{2}{*}{ Covariates } & \multirow{2}{*}{$\begin{array}{l}\text { Savings only } \\
\text { (\% or X) }\end{array}$} & \multirow{2}{*}{$\begin{array}{l}\text { Comparison } \\
(\% \text { or } \mathrm{X})\end{array}$} & \multicolumn{2}{|c|}{ Balance } & \multirow{2}{*}{$\begin{array}{l}\text { Savings } \\
\text { only } \\
(\% \text { or } \mathrm{X})\end{array}$} & \multirow{2}{*}{$\begin{array}{c}\text { Comparison } \\
(\% \text { or } \mathrm{X})\end{array}$} & \multicolumn{2}{|c|}{ Balance } \\
\hline & & & $\beta$ & $\begin{array}{l}\text { Robust } \\
\text { SE }\end{array}$ & & & $\beta$ & $\begin{array}{c}\text { Robust } \\
\text { SE }\end{array}$ \\
\hline Home scale & 1.06 & 1.09 & -0.607 & 0.4 & 1.16 & 1.05 & $2.633^{*}$ & 1.026 \\
\hline Head's education level & 12.85 & 13.01 & -0.031 & 0.034 & 13.12 & 12.78 & 0.066 & 0.061 \\
\hline Head is married & 68 & 64 & 0.163 & 0.179 & 69 & 62 & 0.334 & 0.337 \\
\hline Head is not married & 32 & 36 & & & 31 & 38 & & \\
\hline $\begin{array}{l}\text { Parent expects child to } \\
\text { graduate }\end{array}$ & 38 & 60 & $-0.876^{* *}$ & 0.173 & 66 & 47 & 0.754 & 0.316 \\
\hline $\begin{array}{l}\text { Parent does not expect child } \\
\text { to graduate from college }\end{array}$ & 62 & 40 & & & 35 & 52 & & \\
\hline Household net worth & 8.83 & 9.25 & -0.023 & 0.019 & 9.60 & 8.68 & 0.281 & 0.044 \\
\hline Household income & 9.7 & 9.73 & -0.003 & 0.025 & 9.80 & 9.52 & 0.035 & 0.049 \\
\hline Child's race Black & 32 & 50 & $-0.757 * * *$ & 0.179 & 33 & 53 & $-0.858 *$ & 0.334 \\
\hline Child's race White & 68 & 50 & & & 67 & 47 & & \\
\hline Child's age in 2002 & 16.98 & 16.19 & $0.307 * * *$ & 0.056 & 15.85 & 16.43 & -0.208 & 0.136 \\
\hline Child's self-efficacy & 2.99 & 3.08 & -0.246 & 0.123 & 3.20 & 2.99 & 0.520 & 0.349 \\
\hline Child's self-concept & 3.42 & 3.43 & -0.06 & 0.189 & 3.49 & 3.39 & 0.600 & 0.441 \\
\hline $\begin{array}{l}\text { Child's academic achieve- } \\
\text { ment }\end{array}$ & 200.2 & 206.81 & $-0.001^{*}$ & 0 & 215.26 & 201.37 & 0.002 & 0.001 \\
\hline $\begin{array}{l}\text { Child expects most/all peers } \\
\text { to graduate from college }\end{array}$ & 57 & 76 & $-0.875^{* * *}$ & 0.175 & 75 & 70 & 0.264 & 0.305 \\
\hline \multirow{3}{*}{$\begin{array}{l}\text { Attended private school } \\
\text { Did not attend private } \\
\text { school }\end{array}$} & 43 & 24 & & & 25 & 30 & & \\
\hline & 3 & 8 & & & 19 & 5 & 1.350 & 0.739 \\
\hline & 97 & 92 & -1.06 & 0.472 & 81 & 95 & & \\
\hline
\end{tabular}

Source: Weighted data from the Panel Study of Income Dynamics and its supplements. Notes: Data imputed using multiple imputations. Estimates are propensity score-adjusted using the weighting scheme in Guo \& Fraser, 2010 (also see Foster, 2003 and Imbens, 2000). The propensity score weights are based on the propensity scores (or predicted probabilities) calculated using the results of the multinomial logit model. Comparison groups consist of all children not in the dose category. The term certain identifies children who expected to graduate from a four-year college prior to leaving high school.* $p<.05 ;{ }^{* *} p<.01 ;{ }^{* * *} p<.001$. 


\section{Appendix B}

Table 2.

Covariate balance in 1003 matched pairs of a no savings/uncertain dose, savings only dose, certain to graduate dose only and combination dose after adjusting for propensity score weight.

\begin{tabular}{|c|c|c|c|c|c|c|c|c|}
\hline \multirow{2}{*}{ Covariates } & \multirow{2}{*}{$\begin{array}{c}\text { Certain Only } \\
\text { (\% or X) }\end{array}$} & \multirow{2}{*}{$\begin{array}{c}\text { Comparison } \\
(\% \text { or X) }\end{array}$} & \multicolumn{2}{|c|}{ Balance } & \multirow{2}{*}{$\begin{array}{l}\text { Certain Only } \\
(\% \text { or X) }\end{array}$} & \multirow{2}{*}{$\begin{array}{c}\text { Comparison } \\
(\% \text { or } \mathrm{X})\end{array}$} & \multicolumn{2}{|c|}{ Balance } \\
\hline & & & $\beta$ & $\begin{array}{c}\text { Robust } \\
\text { SE }\end{array}$ & & & $\beta$ & $\begin{array}{c}\text { Robust } \\
\text { SE }\end{array}$ \\
\hline Home scale & 1.05 & 1.09 & $-0.906^{*}$ & 0.356 & 1.05 & 1.09 & -0.541 & 0.668 \\
\hline Head's education level & 12.33 & 13.19 & $-0.168^{* * *}$ & 0.033 & 13.02 & 12.80 & 0.044 & 0.159 \\
\hline Head is married & 54 & 68 & $-0.611 * * *$ & 0.152 & 67 & 63 & 0.210 & 0.232 \\
\hline Head is not married & 46 & 32 & & & 33 & 37 & & \\
\hline Parent expects child to graduate & 53 & 57 & -0.179 & 0.149 & 53 & 51 & 0.079 & 0.236 \\
\hline $\begin{array}{l}\text { Parent does not expect child to } \\
\text { graduate }\end{array}$ & 47 & 43 & & & 47 & 49 & & \\
\hline Household net worth & 8.26 & 9.47 & $-0.063 * * *$ & 0.016 & 9.10 & 8.63 & 0.024 & 0.077 \\
\hline Household income & 9.3 & 9.86 & $-0.049^{*}$ & 0.02 & 9.51 & 9.62 & -0.009 & 0.036 \\
\hline Child's race Black & 73 & 39 & $1.457 * * *$ & 0.164 & 47 & 49 & -0.104 & 0.232 \\
\hline Child's race White & 27 & 61 & & & 53 & 51 & & \\
\hline Child's age in 2002 & 15.95 & 16.44 & $-0.189 * * *$ & 0.047 & 16.44 & 16.26 & 0.060 & 0.076 \\
\hline Child's self-efficacy & 3.03 & 3.07 & -0.118 & 0.124 & 3.01 & 3.06 & -0.077 & 0.188 \\
\hline Child's self-concept & 3.455 & 3.42 & 0.174 & 0.164 & 3.45 & 3.40 & 0.182 & 0.248 \\
\hline Child's academic achievement & 196.37 & 208.57 & $-0.004 * * *$ & 0.001 & 204.63 & 204.55 & 0.000 & 0.003 \\
\hline $\begin{array}{l}\text { Child expects most/all peers to } \\
\text { graduate }\end{array}$ & 76 & 72 & 0.179 & 0.171 & 67 & 71 & -0.012 & 0.250 \\
\hline Attended private school & 24 & 28 & & & 36 & 29 & & \\
\hline Did not attend private school & 5 & 8 & -0.363 & 0.316 & 9 & 8 & 0.124 & 0.649 \\
\hline \multirow{2}{*}{ Covariates } & \multirow{2}{*}{$\begin{array}{l}\text { Combined } \\
(\% \text { or } \mathrm{X})\end{array}$} & \multirow{2}{*}{$\begin{array}{c}\text { Comparison } \\
(\% \text { or } \mathrm{X})\end{array}$} & \multicolumn{2}{|c|}{ Balance } & \multirow{2}{*}{$\begin{array}{l}\text { Combined } \\
(\% \text { or } \mathrm{X})\end{array}$} & \multirow{2}{*}{$\begin{array}{c}\text { Comparison } \\
(\% \text { or } X)\end{array}$} & \multicolumn{2}{|c|}{ Balance } \\
\hline & & & $\beta$ & $\begin{array}{l}\text { Robust } \\
\text { SE }\end{array}$ & & & $\beta$ & $\begin{array}{l}\text { Robust } \\
\text { SE }\end{array}$ \\
\hline Home scale & 1.05 & 1.09 & $-0.906^{*}$ & 0.356 & 1.06 & 1.08 & -0.519 & 0.721 \\
\hline Head's education level & 12.33 & 13.19 & $-0.168 * * *$ & 0.033 & 12.81 & 12.88 & -0.014 & 0.063 \\
\hline Head is married & 54 & 68 & $-0.611 * * *$ & 0.152 & 55 & 67 & $-0.559^{*}$ & 0.262 \\
\hline Head is not married & 46 & 32 & & & 45 & 33 & & \\
\hline Parent expects child to graduate & 53 & 57 & -0.179 & 0.149 & 44 & 55 & -0.445 & 0.242 \\
\hline $\begin{array}{l}\text { Parent does not expect child to } \\
\text { graduate }\end{array}$ & 47 & 43 & & & 56 & 45 & & \\
\hline Household net worth & 8.26 & 9.47 & $-0.063 * * *$ & 0.016 & 7.80 & 9.14 & -0.065 & 0.032 \\
\hline Household income & 9.3 & 9.86 & $-0.049^{*}$ & 0.02 & 9.64 & 9.57 & 0.006 & 0.037 \\
\hline Child's race Black & 73 & 39 & $1.457 * * *$ & 0.164 & 59 & 44 & $0.594 *$ & 0.239 \\
\hline Child's race White & 27 & 61 & & & 41 & 56 & & \\
\hline Child's age in 2002 & 15.95 & 16.44 & $-0.189 * * *$ & 0.047 & 16.28 & 16.31 & -0.009 & 0.076 \\
\hline Child's self-efficacy & 3.03 & 3.07 & -0.118 & 0.124 & 2.94 & 3.09 & -0.355 & 0.214 \\
\hline Child's self-concept & 3.455 & 3.42 & 0.174 & 0.164 & 3.45 & 3.40 & 0.238 & 0.277 \\
\hline Child's academic achievement & 196.37 & 208.57 & $-0.004 * * *$ & 0.001 & 200.03 & 206.58 & -0.003 & 0.002 \\
\hline $\begin{array}{l}\text { Child expects most/all peers to } \\
\text { graduate from college }\end{array}$ & 76 & 72 & 0.179 & 0.171 & 68 & 72 & -0.224 & 0.241 \\
\hline Attended private school & 24 & 28 & & & 32 & 28 & & \\
\hline Did not attend private school & 5 & 8 & -0.363 & 0.316 & 6 & 10 & -0.616 & 0.522 \\
\hline
\end{tabular}

Source: Weighted data from the Panel Study of Income Dynamics and its supplements. Notes: Data imputed using multiple imputations. The weights (adjusted) are based on the propensity scores (or predicted probabilities) calculated using the results of the multinomial logit model. Comparison groups consist of all children not in the dose category. Estimates are propensity score-adjusted using the weighting scheme in Guo \& Fraser, 2010 (also see Foster, 2003 and Imbens, 2000). The propensity score weights are based on the propensity scores (or predicted probabilities) calculated using the results of the multinomial logit model. The term certain identifies children who expected to graduate from a four-year college prior to leaving high school.* $p<.05 ; * * p<.01 ; * * * p<.001$. 